УДК 615.012.1:547.789.1

DOI https://doi.org/10.11603/2312-0967.2019.1.9930

\title{
СИНТЕЗ ДЕЯКИХ ПОХІДНИХ 3-(5-МЕРКАПТО-[1,3,4]ОКСОДІАЗОЛ-2-ІЛ-МЕТИЛ)- 5,7-ДИМЕТИЛ-ЗН-ТІАЗОЛО[4,5-В]ПІРИДИН-2-ОНУ ЯК ПОТЕНЦІЙНИХ БІОЛОГІЧНО АКТИВНИХ РЕЧОВИН
}

\author{
T. І. Чабан \\ Львівський національний медичний університет імені Данила Галицького \\ chabantaras@ukr.net
}

\begin{abstract}
Мета роботи. Розширення синтетичного потенціалу тіазоло[4,5-b]піридинів, дослідження їхньої реакційної здатності та синтез деяких нових 3-(5-меркапто-[1,3,4]оксодіазол-2-іл-метил)-5,7-диметил-3Н-тіазоло[4,5-b] піридин-2-онів.

Матеріали і методи. Методи органічного синтезу, ${ }^{1} \mathrm{H}$ ЯМР-спектроскопія, елементний аналіз.

Результати й обговорення. Для розширення комбінаторної бібліотеки тіазолопіридинів, проведено структурну модисрікацію тіольної групи 3-(5-меркапто-[1,3,4]оксодіазол-2-іл-метил)-5,7-диметил-3Н-тіазоло[4,5-b] піридин-2-ону за реакціями ціанетилювання та алкілювання. Як алкілюючі агенти апробовано етиловий естер монохлорацетатної кислоти та деякі хлорацетаміди, що дозволило отримати серію нових похідних базового скафолду.

Висновки. Встановлено, що 3-(5-меркапто-[1,3,4]оксодіазол-2-іл-метил)-5,7-диметил-3Н-тіазоло[4,5-b]піридин2-он вступає у реакцію ціанетилювання, а також утворює солі з лугами. Отримана сіль 3-(5-меркапто-[1,3,4] оксодіазол-2-іл-метил)-5,7-диметил-3Н-тіазоло[4,5-b]піридин-2-ону алкілюється 3 утворенням відповідних похідних. Ми продовжуємо дослідження реакційної здатності, а також хімічних перетворень із перспективою вивчення біологічної активності синтезованих сполук.
\end{abstract}

Ключові слова: тіазоло[4,5-b]піридини; ціанетилювання; алкілювання.

Вступ. Органічні сполуки гетероциклічної природи складають на сьогодні близько 70 \% усіх застосовуваних у клініці лікарських засобів. Найбільш широко використовуються препарати, що містять у своїй структурі азотовмісні гетероциклічні системи [1]. Серед низки таких сполук, тіазолідини, завдяки широкому спектру біологічної дії своїх численних похідних, мають дуже важливе значення [2]. Проте синтез та біологічна активність конденсованих гетероциклів 3 тіазолідиноновим фррагментом досліджені недостатньо $[3,4]$.

Тіазолопіридини як біоізостери пурину - важливий тип гетероциклічних систем, інтенсивне дослідження яких зумовлене як чималим діапазоном їх фрармакологічної активності, так і синтетичними можливостями для функціоналізації похідних за різними положеннями базового скафолду. Вони проявляють антимікробну [5], антиоксидантну [6], протигрибкову [7] та протизапальну [8] активності, $€$ агоністами $\mathrm{H}_{3}$ гістамінових рецепторів [9], антагоністами метаботропних глутаматних рецепторів 5 (mGluR5) [10], речовинами з високою інгібуючої активністю щодо рецепторів епідермального фрактора росту [11] та ряду інших фрерментів [12]. Тому, безумовно, синтез тіазолідинів анельованих з піридиновим циклом є цікавим і актуальним для раціонального дизайну біологічно активних сполук.
Матеріали і методи. При виконанні експериментальної частини роботи використано традиційні методи органічного синтезу. Синтетичні дослідження проведено 3 використанням реактивів компаній «Merck» (Дармштадт, Німеччина) та «Sigma-Aldrich» (Міссурі, США). Спектри ${ }^{1} \mathrm{H}$ ЯМР одержаних сполук знімались на приладі Varian VXR-400, розчинник DMSO-d6, стандарт - тетраметилсилан. Дані елементного аналізу на вміст Нітрогену та Сульфуру відповідають вирахуваним ( $\pm 0,3 \%)$.

Результати й обговорення. Продовжуючи систематичне вивчення тіазоло[4,5-b]піридинів як потенційних біологічно активних сполук, було здійснено синтез нових похідних 3-(5-меркапто-[1,3,4] оксодіазол-2-іл-метил)-5,7-диметил-3Н-тіазоло[4,5- $b$ ] піридин-2-ону (1). Зазначений скафолд було отримано шляхом взаємодії еквімолярної кількості, яку ми отримали раніше гідразиду (5,7-диметил-2-оксотіазоло[4,5-b]піридин-3-іл)-ацетатної кислоти [13], сірковуглецю та КОН при 6-годинному кип'ятінні зазначеної суміші в середовищі етанолу (схема).

SH-нуклеофільний центр із рухливим атомом гідрогену сполуки 1 дає можливість для синтезу S-заміщених похідних. Зокрема, тіольна група сполуки 1 дає можливість для синтезу на її основі відповідного похідного за реакцією ціанетилювання. Встановлено, що найоптимальніші умови для введення

ISSN 2312-0967. Pharmaceutical review. 2019. № 1 
Синтез біологічно активних сполук

Synthesis of biologically active compounds

$\beta$-ціанетильного фррагменту по тіольній групі базового скафролду полягають у взаємодії еквімолярних кількостей 3-(5-меркапто-[1,3,4]оксодіазол-2-ілметил)-5,7-диметил-3Н-тіазоло[4,5-b]піридин-2-ону 3 акрилонітрилом в середовищі піридину і води у співвідношенні 5:1, це дало можливість отримати відповідний 3-[5-(5,7-диметил-2-оксо-тіазоло[4,5-b] піридин-3-ілметил)-[1,3,4]оксодіазол-2-ілсульсранілпропіонітрил (2) (схема). Зазначене перетворення відбувається як спряжене нуклеофільне 1,4 приєднання.

Наступний етап даної роботи полягав у встановленні можливості отримання солей на основі сполуки 1 та дослідженні їх реакційної здатності. 3 іншої точки зору біодоступність солей значно вища, ніж відповідних кислот, що робить їх перспективними у фармакологічних дослідженнях. Як було встановлено, 3 синтетичної точки зору найбільш перспективною виявилась калійна сіль (3) (схема). На відміну від більшості солей азолідонів, зазначена речовина стійка у водних розчинах [14].

3 метою вивчення впливу різноманітних замісників у молекулах на характер біологічної активності тіазоло[4,5-b]піридин-2-онів синтезовано серії нових сполук із естерними та ацетамідними фррагментами в положенні $\mathrm{S}^{5}$ оксадіазольного циклу базового скафолду, враховуючи значний фрармакологічний потенціал споріднених похідних 4-азолідон-3-алканкарбонових кислот [14]. Сполука 3 проявляє нуклеофрільні властивості і в м'яких умовах реагує з електрофрільними реагентами, що дає можливість отримати ряд продуктів S-алкілювання. Одним 3 напрямків структурної модісрикації сполуки 3 став синтез етилового естеру [5-(5,7-диметил-2-оксо-тіазоло[4,5-b] піридин-3-ілметил)-[1,3,4]оксодіазол-2-іл-сульсраніл]ацетатної кислоти (4) (схема). Для здійснення цього перетворення вивчалася реакція алкілювання сполуки 3 етиловим естером монохлорацетатної кислоти. Реакцію проведено в середовищі ДМФА при кип'ятінні протягом 1 години. Для синтезу амідів [5-(5,7-диметил-2-оксо-тіазоло[4,5-b]піридин-3ілметил)-[1,3,4]оксодіазол-2-іл-сульфраніл]ацетатної кислоти 5-12, алкілювання сполуки 3 проводилося серією арилхлорацетамідів (схема). Зазначене перетворення відбувається в умовах ідентичних синтезу сполуки 4.

Для підтвердження структури та індивідуальності синтезованих речовин використано методи кількісного елементного аналізу та спектроскопії ЯМР ${ }^{1} \mathrm{H}$. Сигнали протонів метильних груп піридинового циклу усіх синтезованих сполук спостерігаються при 2.312.34 м.ч. і 2.40-2.45 м.ч. відповідно. Тіольна групи сполуки 1 характеризується синглетом в області 14.56 м.ч., що доводить отримання цільового 3-(5-меркапто-[1,3,4]оксодіазол-2-іл-метил)-5,7-диметил-3Нтіазоло[4,5-b]піридин-2-ону. Спектри ПМР сполуки 2 представлені двома триплетами екзоциклічних метиленових груп при 3.00 та 4.28 м.ч., що підтверджує проходження реакції ціанетилювання. Відсутність сигналу тіольної групи засвідчує отримання калійної солі сполуки 1. Отримання цільових сполук 4-12 характеризує наявність екзоциклічної метиленової групи представленої синглетом в ділянці 4.18-4.34 м.ч. Спектральні характеристики синтезованих сполук наведено в експериментальній частині.

\section{Експериментальна частина.}

3-(5-Меркапто-[1,3,4]оксодіазол-2-іл-метил)5,7-диметил-3н-тіазоло[4,5-b]піридин-2-он (1).<smiles></smiles>

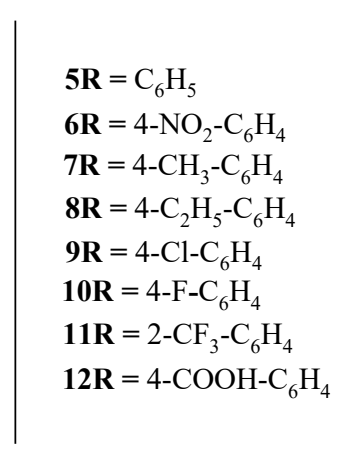<smiles>[R]NC(=O)CSc1nnc(Cn2c(=O)sc3c(C)cc(C)nc32)o1</smiles>

Схема. Синтез 3-(5-меркапто-[1,3,4]оксодіазол-2-іл-метил)-5,7-диметил-3Н-тіазоло[4,5-b]піридин-2-ону та його деяких нових похідних.

ISSN 2312-0967. Фармацевтичний часопис. 2019. № 1 
Синтез біологічно активних сполук Synthesis of biologically active compounds

0,006 моль калію гідроксиду розчиняють в 10 мл етанолу. До отриманого розчину додають 0,006 моль сірковуглецю і 0,006 моль гідразиду (5,7-диметил-2оксо-тіазоло[4,5-b]піридин-3-іл)-ацетатної кислоти. Суміш нагрівають на киплячому водяному огрівнику протягом 6 годин. Розчин охолоджують та підкислюють 5 \% хлоридною кислотою до $\mathrm{pH} \sim 5$, розбавляють п'ятикратно водою, осад відфрільтровують, промивають водою і висушують. Після перекристалізації 3 ацетатної кислоти білий кристалічний порошок, добре розчинний в ДМФА, ДМСО, розчинах лугів і мінеральних кислот, погано - в інших органічних розчинниках. Вихід $-65 \%$, Тпл. $-144^{\circ} \mathrm{C}$. Спектр ЯМР ${ }^{1} \mathrm{H}, \delta$, м.4.: $2.33 \mathrm{c}\left(3 \mathrm{H}, \mathrm{CH}_{3}\right), 2.44 \mathrm{c}\left(3 \mathrm{H}, \mathrm{CH}_{3}\right), 5.28 \mathrm{c}(2 \mathrm{H}$, $\left.\mathrm{CH}_{2}\right), 7.05$ с (1H, Рy.), 14.56 с (1H, SH). Знайдено, \%: $\mathrm{N}$ 18.88, S 21.61. $\mathrm{C}_{11} \mathrm{H}_{10} \mathrm{~N}_{4} \mathrm{O}_{2} \mathrm{~S}_{2}$. Обчислено, \%: N 19.03, S 21.79.

3-[5-(5,7-Диметил-2-оксо-тіазоло[4,5-b] піридин-3-ілметил)-[1, 3,4]оксодіазол-2 ілсульфаніл-пропіонітрил (2). До 0,01моля сполуки 1 додають суміш 50 мл піридину і 10 мл води, що містить 3 мл акрилонітрилу. Реакційну суміш нагрівають 5 год в колбі зі зворотним холодильником. Кристалічний осад, одержаний осадженням за допомогою води. Після перекристалізації 3 ацетатної кислоти кремовий порошок розчинний у ДМФА, ДМСО, ацетатній кислоті. Вихід - $54 \%$, Тпл. - $135^{\circ} \mathrm{C}$. Спектр ЯMP ${ }^{1} \mathrm{H}, \delta$, м.ч.: $2.34 \mathrm{c}\left(3 \mathrm{H}, \mathrm{CH}_{3}\right), 2.44 \mathrm{c}\left(3 \mathrm{H}, \mathrm{CH}_{3}\right), 3.00$ $\mathrm{T}\left(2 \mathrm{H}, \mathrm{J}=6.3\right.$ Гц, $\left.\mathrm{CH}_{2}\right), 4.28 \mathrm{~T}\left(2 \mathrm{H}, \mathrm{J}=6.3\right.$ Гц, $\left.\mathrm{CH}_{2}\right), 5.34$ с $\left(2 \mathrm{H}, \mathrm{CH}_{2}\right), 7.07$ с (1Н, Ру.). Знайдено, \%: N 20.33, $\mathrm{S}$ 18.22. $\mathrm{C}_{14} \mathrm{H}_{15} \mathrm{~N}_{5} \mathrm{O}_{2} \mathrm{~S}_{2}$. Обчислено, \%: N 20.16, S 18.46.

Калійна сіль 3-(5-меркапто-[1,3,4]оксодіазол2-іл-метил)-5,7-диметил-зН-тіазоло[4,5-b] піридин-2-ону (3). 0,03 моль сполуки 1 вносять у розчин, приготований з 50 мл води і 0,03 ммоль калію гідроксиду. Суміш нагрівають до повного розчинення. Одержаний розчин охолоджують, осад відфільтровують, промивають водою і висушують. Після перекристалізації з ацетатної кислоти - білий кристалічний порошок розчинний у воді і спиртах; малорозчинний в органічних розчинниках. Вихід - $60 \%$, Тпл. 154-155 ${ }^{\circ} \mathrm{C}$. Спектр ЯМР ${ }^{1} \mathrm{H}, \delta$, м.4.: $2.32 \mathrm{c}\left(3 \mathrm{H}, \mathrm{CH}_{3}\right)$, 2.44 c $\left(3 \mathrm{H}, \mathrm{CH}_{3}\right), 5.11$ c $\left(2 \mathrm{H}, \mathrm{CH}_{2}\right), 7.03$ c $(1 \mathrm{H}$, Py. $)$. Знайдено, \%: N 16.72, S 19.35. $\mathrm{C}_{11} \mathrm{H}_{9} \mathrm{KN}_{4} \mathrm{O}_{2} \mathrm{~S}_{2}$. Обчислено, \%: N 16.85, S 19.29.

Загальна методика синтезу S-заміщених 3-(5-меркапто-[1,3,4]оксодіазол-2-іл-метил)-5,7диметил-зН-тіазоло[4,5-b]піридин-2-онів (4-12) за реакцією алкілювання. До розчину, одержаного при нагріванні 0,009 моль сполуки 3 в 12 мл ДМФА, додають 0,009 моль відповідного алкілюючого агента. Суміш кип'ятять протягом 60 хвилин, спостерігаючи випадання білого осаду. Потім гарячу суміш фрільтрують, осад на фрільтрі промивають гарячим ДМФА. До фрільтрату, охолодженого до температури близько $50{ }^{\circ} \mathrm{C}$, додають при помішуванні 100 мл води і охолоджують до 10-15 ㅇ. Осад, що випав, відфільтрову- ють, промивають водою і висушують спочатку на повітрі, а потім при $60^{\circ} \mathrm{C}$. Перекристалізовують 3 ацетатної кислоти. Одержані сполуки - білі, кремові або сірі порошки, розчинні у спиртах, хлороформі, діоксані, ДМФА, ацетатній кислоті, не розчинні у воді.

Етиловий естер [5-(5,7-диметил-2-оксотіазоло[4, 5-b]піридин-3-ілметил)-[1, 3,4] оксодіазол-2-іл-сульфаніл]-ацетатної кислоти (4). Вихід - $71 \%$, Тпл. - $108{ }^{\circ} \mathrm{C}$. Спектр ЯМР ${ }^{1} \mathrm{H}, \delta$, М.4.: 1.15 т $\left(3 \mathrm{H}, \mathrm{J}=7.1\right.$ Гц, $\left.\mathrm{CH}_{2}-\mathrm{CH}_{3}\right), 2.33 \mathrm{c}\left(3 \mathrm{H}, \mathrm{CH}_{3}\right)$, $2.43 \mathrm{C}\left(3 \mathrm{H}, \mathrm{CH}_{3}\right), 4.01 \mathrm{M}\left(2 \mathrm{H}, \mathrm{CH}_{2}^{-}-\mathrm{CH}_{3}\right), 4.18 \mathrm{c}(2 \mathrm{H}$, S- $\left.\underline{\mathrm{CH}}_{2}\right), 5.40$ c $\left(2 \mathrm{H}, \mathrm{CH}_{2}\right), 7.05$ c $(1 \mathrm{H}$, Ру. $)$. Знайдено, \%: $\mathrm{N} 14.55, \mathrm{~S}$ 16.99. $\mathrm{C}_{15} \mathrm{H}_{16} \mathrm{~N}_{4} \mathrm{O}_{4} \mathrm{~S}_{2}$. Обчислено, \%: N 14.73, S 16.86 .

2-[5-(5,7-Диметил-2-оксо-тіазоло[4,5-b] піридин-3-ілметил)-[1,3,4]оксодіазол-2-ілсульфаніл]-N-френіл-ацетамід (5). Вихід - 68 \%, Тпл. $-212^{\circ} \mathrm{C}$. Спектр ЯМР ${ }^{1} \mathrm{H}, \delta$, м.ч.: $2.33 \mathrm{c}\left(3 \mathrm{H}, \mathrm{CH}_{3}\right)$, $2.45 \mathrm{c}\left(3 \mathrm{H}, \mathrm{CH}_{3}\right), 4.28 \mathrm{c}\left(2 \mathrm{H}, \mathrm{S}-\mathrm{CH}_{2}\right), 5.32 \mathrm{c}\left(2 \mathrm{H}, \mathrm{CH}_{2}\right)$, 7.04 с (1H, Py.), 7.18-7.23 м $\left(2 \mathrm{H}, \mathrm{C}_{6} \mathrm{H}_{5}\right), 7.36-7.43$ м (3H, $\left.\mathrm{C}_{6} \mathrm{H}_{5}\right), 10.77$ с (1H, NH). Знайдено, \%: N 16.44, S 14.88 . $\mathrm{C}_{19} \mathrm{H}_{17} \mathrm{~N}_{5} \mathrm{O}_{3} \mathrm{~S}_{2}$. Обчислено, \%: N 16.38, S 15.00.

2-[5-(5,7-Диметил-2-оксо-тіазоло[4,5-b] піридин-3-ілметил)-[1,3,4]оксодіазол-2-ілсульфраніл]-N-(4-нітро-феніл)-ацетамід (6). Вихід - $55 \%$, Тпл. $-198^{\circ} \mathrm{C}$. Спектр ЯМР ${ }^{1} \mathrm{H}, \delta$, м.4.: 2.34 с $\left(3 \mathrm{H}, \mathrm{CH}_{3}\right), 2.44 \mathrm{c}\left(3 \mathrm{H}, \mathrm{CH}_{3}\right), 4.31 \mathrm{c}\left(2 \mathrm{H}, \mathrm{S}-\underline{\mathrm{CH}}_{2}\right), 5.26 \mathrm{c}$ $\left(2 \mathrm{H}, \mathrm{CH}_{2}\right), 7.02$ с (1H, Ру. $), 7,21$ д $\left(2 \mathrm{H}, \mathrm{J}=8,0\right.$ Гц, $\left.\mathrm{C}_{6} \mathrm{H}_{5}\right)$, 7,89 д $\left(2 \mathrm{H}, \mathrm{J}=8,0\right.$ Гц, $\left.\mathrm{C}_{6} \mathrm{H}_{5}\right), 10.84$ с $(1 \mathrm{H}, \mathrm{NH})$. Знайдено, \%: N 17.62, S 13.45. C $19 \mathrm{H}_{16} \mathrm{~N}_{6} \mathrm{O}_{5} \mathrm{~S}_{2}$. Обчислено, \%: N 17.79, S 13.57 .

2-[5-(5,7-Диметил-2-оксо-тіазоло[4,5-b] піридин-3-ілметил)-[1,3,4]оксодіазол-2-ілсульфраніл]-N-(4-толіл-френіл)-ацетамід (7). Вихід - $55 \%$, Тпл. - $234{ }^{\circ} \mathrm{C}$. Спектр ЯМР ${ }^{1} \mathrm{H}, \delta$, м.4.: 2.18 с $\left(3 \mathrm{H}, \mathrm{C}_{6} \mathrm{H}_{4}-\mathrm{CH}_{3}\right), 2.31 \mathrm{c}\left(3 \mathrm{H}, \mathrm{CH}_{3}\right), 2.40 \mathrm{c}\left(3 \mathrm{H}, \mathrm{CH}_{3}\right), 4.26$ C $\left(2 \mathrm{H}, \mathrm{S}-\mathrm{CH}_{2}\right), 5.28 \mathrm{c}\left(2 \mathrm{H}, \mathrm{CH}_{2}\right), 7.00 \mathrm{c}(1 \mathrm{H}, \mathrm{Py}), 7,$.15 д $\left(2 \mathrm{H}, \mathrm{J}=7,9\right.$ Гц, $\left.\mathrm{C}_{6} \mathrm{H}_{4}\right), 7,84$ д $\left(2 \mathrm{H}, \mathrm{J}=7,9\right.$ Гц, $\left.\mathrm{C}_{6} \mathrm{H}_{4}\right), 10.88$ c $(1 \mathrm{H}, \mathrm{NH})$. Знайдено, \%: $\mathrm{N} 15.77, \mathrm{~S} 14.39$. $\mathrm{C}_{20} \mathrm{H}_{19} \mathrm{~N}_{5} \mathrm{O}_{3} \mathrm{~S}_{2}$. Обчислено, \%: N 15.86, S 14.52.

2-[5-(5,7-Диметил-2-оксо-тіазоло[4,5-b] піридин-3-ілметил)-[1,3,4]оксодіазол-2-ілсульфраніл]-N-(4-етил-френіл)-ацетамід (8). Вихід - $64 \%$, Тпл. $-211{ }^{\circ} \mathrm{C}$. Спектр ЯМР ${ }^{1} \mathrm{H}, \delta$, м.4.: 1,17 т $\left(3 \mathrm{H}, \mathrm{J}=7,3\right.$ Гц, $\left.\mathrm{CH}_{2}-\mathrm{CH}_{3}\right), 2.34 \mathrm{c}\left(3 \mathrm{H}, \mathrm{CH}_{3}\right), 2.44 \mathrm{c}(3 \mathrm{H}$, $\left.\mathrm{CH}_{3}\right), 3.97$ м $\left(2 \mathrm{H}, \mathrm{CH}_{2}-\mathrm{CH}_{3}\right), 4.28 \mathrm{c}\left(2 \mathrm{H}, \mathrm{S}-\underline{\mathrm{CH}}_{2}\right), 5.24 \mathrm{C}$ $\left(2 \mathrm{H}, \mathrm{CH}_{2}\right), 7.05$ с $(1 \mathrm{H}$, Рy. $), 7,11$ д $\left(2 \mathrm{H}, \mathrm{J}=7,9\right.$ Гц, $\left.\mathrm{C}_{6} \mathrm{H}_{4}\right)$, 7,79 д $\left(2 \mathrm{H}, \mathrm{J}=7,9\right.$ Гц, $\left.\mathrm{C}_{6} \mathrm{H}_{4}\right), 10.82$ с $(1 \mathrm{H}, \mathrm{NH})$. Знайдено, \%: N 15.44, S 14.02. $\mathrm{C}_{21} \mathrm{H}_{21} \mathrm{~N}_{5} \mathrm{O}_{3} \mathrm{~S}_{2}$. Обчислено, \%: N 15.37, S 14.08 .

2-[5-(5,7-Диметил-2-оксо-тіазоло[4,5-b] піридин-3-ілметил)-[1,3,4]оксодіазол-2-ілсульфраніл]-N-(4-хлор-феніл)-ацетамід (9). Вихід - $66 \%$, Тпл. $-192{ }^{\circ} \mathrm{C}$. Спектр ЯМР ${ }^{1} \mathrm{H}, \delta$, м.4.: 2.33 с $\left(3 \mathrm{H}, \mathrm{CH}_{3}\right), 2.44 \mathrm{c}\left(3 \mathrm{H}, \mathrm{CH}_{3}\right), 4.34 \mathrm{c}\left(2 \mathrm{H}, \mathrm{S}-\underline{\mathrm{CH}}_{2}\right), 5.33 \mathrm{c}$ $\left(2 \mathrm{H}, \mathrm{CH}_{2}\right), 7.03$ с $(1 \mathrm{H}, \mathrm{Py}), 7,$.18 д $\left(2 \mathrm{H}, \mathrm{J}=8,0\right.$ Гц, $\left.\mathrm{C}_{6} \mathrm{H}_{4}\right)$, 7,76 д $\left(2 \mathrm{H}, \mathrm{J}=7,9\right.$ Гц, $\left.\mathrm{C}_{6} \mathrm{H}_{4}\right), 10.88$ с (1H, NH). Знайде- 
Синтез біологічно активних сполук

Synthesis of biologically active compounds

но, \%: N 14.98, S 13.99. $\mathrm{C}_{19} \mathrm{H}_{16} \mathrm{ClN}_{5} \mathrm{O}_{3} \mathrm{~S}_{2}$. ОбчислеHO, \%: N 15.16, S 13.88.

2-[5-(5,7-Диметил-2-оксо-тіазоло[4,5-b]піридин3-ілметил)-[1,3,4]оксодіазол-2-іл-сульфраніл]-N-(4фртор-феніл)-ацетамід (10). Вихід - 59 \%, Тпл. $177^{\circ} \mathrm{C}$. Спектр ЯМР ${ }^{1} \mathrm{H}, \delta$, м.ч.: 2.32 с (3H, $\left.\mathrm{CH}_{3}\right), 2.42$ с $\left(3 \mathrm{H}, \mathrm{CH}_{3}\right), 4.31 \mathrm{c}\left(2 \mathrm{H}, \mathrm{S}-\underline{\mathrm{CH}}_{2}\right), 5.33 \mathrm{c}\left(2 \mathrm{H}, \mathrm{CH}_{2}\right), 6.98 \mathrm{c}(1 \mathrm{H}$, Py.), 7,11 д (2H, J=7,9 Гц, $\left.\mathrm{C}_{6} \mathrm{H}_{4}\right), 7,72$ д (2H, J=7,9 Гц, $\left.\mathrm{C}_{6} \mathrm{H}_{4}\right), 10.84$ с (1H, NH). Знайдено, \%: N 15.81, S 14.46. $\mathrm{C}_{19} \mathrm{H}_{16} \mathrm{FN}_{5} \mathrm{O}_{3} \mathrm{~S}_{2}$. Обчислено, \%: N 15.72, S 14.39.

2-[5-(5,7-Диметил-2-оксо-тіазоло[4,5-b] піридин-3-ілметил)-[1,3,4]оксодіазол-2-ілсульфаніл]-N-(2-трифлуорометил-феніл)ацетамід (11). Вихід - 62 \%, Тпл. - $193^{\circ} \mathrm{C}$. Спектр ЯMP ${ }^{1} \mathrm{H}, \delta$, M.4.: $2.34 \mathrm{c}\left(3 \mathrm{H}, \mathrm{CH}_{3}\right), 2.43 \mathrm{c}\left(3 \mathrm{H}, \mathrm{CH}_{3}\right), 4.29$ c $\left(2 \mathrm{H}, \mathrm{S}-\underline{\mathrm{CH}}_{2}\right), 5.35$ с $\left(2 \mathrm{H}, \mathrm{CH}_{2}\right), 7.01$ с $(1 \mathrm{H}, \mathrm{Py}),$.7.18 д $\left(1 \mathrm{H}, \mathrm{J}=6.9\right.$ Гц, $\left.\mathrm{C}_{6} \mathrm{H}_{4}\right), 7.25 \mathrm{~T}\left(1 \mathrm{H}, \mathrm{J}=8.1\right.$ Гц, $\left.\mathrm{C}_{6} \mathrm{H}_{4}\right), 7.37$ д $\left(1 \mathrm{H}, \mathrm{J}=7.8\right.$ Гц, $\left.\mathrm{C}_{6} \mathrm{H}_{4}\right), 7.68-7.71 \mathrm{м}\left(1 \mathrm{H}, \mathrm{C}_{6} \mathrm{H}_{4}\right), 10.89 \mathrm{c}$ $(1 \mathrm{H}, \mathrm{NH})$. Знайдено, \%: N 13.99, S 12.86. $\mathrm{C}_{20} \mathrm{H}_{16} \mathrm{~F}_{3} \mathrm{~N}_{5} \mathrm{O}_{3} \mathrm{~S}_{2}$. Обчислено, \%: N 14.13, S 12.94.

4-\{2-[5-(5,7-Диметил-2-оксо-тіазоло[4,5-b] піридин-3-ілметил)-[1, 3,4]оксодіазол-2-іл- сульфраніл]-ацетиламіно\}-бензойна кислота (12). Вихід - $55 \%$, Тпл. - $234{ }^{\circ} \mathrm{C}$. Спектр ЯМР ${ }^{1} \mathrm{H}, \delta$, м.4.: 2.33 с $\left(3 \mathrm{H}, \mathrm{CH}_{3}\right), 2.44 \mathrm{c}\left(3 \mathrm{H}, \mathrm{CH}_{3}\right), 4.27$ с $(2 \mathrm{H}$, S- $\left.\underline{\mathrm{CH}}_{2}\right), 5.29 \mathrm{c}\left(2 \mathrm{H}, \mathrm{CH}_{2}\right), 7.02 \mathrm{c}(1 \mathrm{H}, \mathrm{Py}), 7.12-7.18 \mathrm{~m}$ $\left(2 \mathrm{H}, \mathrm{C}_{6} \mathrm{H}_{4}\right), 7.70-7.76 \mathrm{M}\left(2 \mathrm{H}, \mathrm{C}_{6} \mathrm{H}_{4}\right), 10.77 \mathrm{c}(1 \mathrm{H}, \mathrm{NH})$, 13.25 с $(1 \mathrm{H}, \mathrm{COOH})$. Знайдено, \%: N 14.81, S 13.56. $\mathrm{C}_{20} \mathrm{H}_{17} \mathrm{~N}_{5} \mathrm{O}_{5} \mathrm{~S}_{2}$. Обчислено, \%: N 14.85, S 13.60.

Висновки. 1. Опрацьовано методику ціанетилювання 3-(5-меркапто-[1,3,4]оксодіазол-2-іл-метил)5,7-диметил-3Н-тіазоло[4,5-b]піридин-2-ону, що дозволило одержати 3-[5-(5,7-диметил-2-оксотіазоло[4,5-b]піридин-3-ілметил)-[1,3,4]оксодіазол-2ілсульфаніл-пропіонітрил.

3-(5-Меркапто-[1,3,4]оксодіазол-2-іл-метил)-5,7диметил-3Н-тіазоло[4,5-b]піридин-2-он утворює солі 3 лугами, а також алкілюються за тіольною групою через стадію утворення калійної солі етиловим естером монохлорацетатної кислоти та серією арилхлорацетамідів.

Конфлікт інтересів: відсутній.

Conflicts of interest: author has no conflict of interest to declare.

\section{СИНТЕЗ НЕКОТОРЫХ ПРОИЗВОДНЫХ 3-(5-МЕРКАПТО-[1,3,4] ОКСОДИАЗОЛ-2-ИЛ-МЕТИЛ)- 5,7-ДИМЕТИЛ-ЗН-ТИАЗОЛО[4,5-В]ПИРИДИН-2-ОНА КАК ПОТЕНЦИАЛЬНЫХ БИОЛОГИЧЕСКИ АКТИВНЫХ ВЕЩЕСТВ}

\section{Т. И. Чабан}

Львовский национальный медицинский университет имени Данила Галицкого chabantaras@ukr.net

Цель работы. Расширение синтетического потенциала тиазоло[4,5-b] пиридинов, исследования их реакционной способности и синтез некоторых новых 3-(5-меркапто-[1,3,4]оксодиазол-2-ил-метил)-5,7-диметил-3Н-тиазоло [4,5b]пиридин-2-онов.

Материалы и методы. Методы органического синтеза, ${ }^{1} \mathrm{H}$ ЯМР-спектроскопия, элементный анализ.

Результаты и обсуждение. Для расширения комбинаторной библиотеки тиазолопиридинов, проведено структурную модификацию тиольной группы 3-(5-меркапто-[1,3,4]оксодиазол-2-ил-метил)-5,7-диметил-3Н-тиазоло[4,5-b] пиридин-2-она за реакциями цианэтилирование и алкилирование. Как алкилирующие агенты апробированы этиловый эфир монохлорацетатной кислоты и некоторые хлорацетамиды, что позволило получить серию новых производных базового скафолда.

Выводы. Установлено, что 3-(5-меркапто-[1,3,4]оксодиазол-2-ил-метил)-5,7-диметил-3Н-тиазоло[4,5-b] пиридин-2-он вступает в реакцию цианэтилирование, а также образует соли со щелочами. Полученная соль 3-(5-меркапто-[1,3,4]оксодиазол-2-ил-метил)-5,7-диметил-3Н-тиазоло[4,5-b]пиридин-2-она алкилируется с образованием соответствующих производних. Мы продолжаем исследование реакционной способности, а также химических превращений с перспективой изучения биологической активности синтезированных соединений.

Ключевые слова: тиазоло[4,5-b]пиридины; цианэтилирование; алкилирование.

ISSN 2312-0967. Фармацевтичний часопис. 2019. № 1 


\title{
SYNTHESIS OF SOME DERIVATIVES 3-(5-MERCAPTO-[1,3,4]OXADIAZOL-2-YLMETHYL)-5,7- DIMETHYL-3H-THIAZOLO[4,5-B]PYRIDIN-2-ONE AS POTENTIAL BIOLOGICALLY ACTIVE COMPOUNDS
}

\author{
T. I. Chaban \\ Danylo Halytsky Lviv National Medical University \\ chabantaras@ukr.net
}

The aim of the work. Expanding the synthetic potential of thiazolo[4,5-b]pyridines, the study of reactivity and synthesis of novel 3-(5-mercapto-[1,3,4]oxadiazol-2-ylmethyl)-5,7-dimethyl-3H-thiazolo[4,5-b]pyridin-2-ones.

Materials and Methods. Methods of organic synthesis, NMR spectroscopy, elemental analysis.

Results and Discussion. To expand the combinatorial library of thiazolopyridines, a structural modification of the thiol group of the 3-(5-mercapto-[1,3,4]oxadiazol-2-ylmethyl)-5,7-dimethyl-3H-thiazolo[4,5-b]pyridin-2-one in reactions cyanoethylation and alkylation was carried out. As alkylating agents, monochloroacetate acid ethyl ester and some chloroacetamides were tested, which made it possible to obtain a series of new derivatives of the basic scaffold.

Conclusions. It was found that 3-(5-mercapto-[1,3,4]oxadiazol-2-ylmethyl)-5,7-dimethyl-3H-thiazolo[4,5-b]pyridin-2one involved into the reaction cyanoethylation, and also forms salts with alkalis. The obtained salt 3-(5-mercapto-[1,3,4] oxadiazol-2-ylmethyl)-5,7-dimethyl-3H-thiazolo[4,5-b]pyridin-2-one possessing nucleophilic properties and the further involved into alkylation reaction using various alkylating agents like ethylchloroacetate and chloroacetamides. We continue to research different activities and chemical transformation of these substances with the prospect of studying biological activities.

Key words: thiazolo[4,5-b]pyridines; cyanethylation; alkylation.

\section{Список літератури}

1. Машковский М. Д. Лекарственные средства / М. Д. Машковский. - М. : Новая волна, 2010. - 1216 с.

2. Lesyk R. B. 4-Thiazolidones: centenarian history, current status and perspectives for modern organic and medicinal chemistry / R. B. Lesyk, B. S. Zimenkovsky // Current Organic Chemistry. - 2004. - Vol. 8 (16). P. 1547-1579.

3. Thiazolo[5,4- $d$ ]pyrimidines and thiazolo[4,5- $d]$ pyrimidines: A review on synthesis and pharmacological importance of their derivatives / T. I. Chaban, O. V. Klenina, I. G. Chaban [et al.] // Pharmacia. - 2018. - Vol. 65 (2). - P. 54-70.

4. Smirnova N. G. Synthesis of condensed thiazoles / N. G. Smirnova, I. V. Zavarzin, M. M. Krayushkin // Chemistry of Heterocyclic Compounds. - 2006. - Vol. 42. - P. 144165.

5. Sayed H. H. Facile novel synthesis and reactions of thiazolidin-4-one derivatives for antimicrobial agents / H. H. Sayed, E. M. H. Morsy, E. R. Kotb // Synthetic communications. - 2010. - Vol. 40. - P. 2712-2722.

6. Synthesis and antioxidant activity evaluation of novel 5,7-dimethyl-3H-thiazolo[4,5-b]pyridines / T. I. Chaban, V. V. Ogurtsov, I. G. Chaban [et al.] // Phosphorus, Sulfur Silicon Relat. Elem. - 2013. - Vol. 188. - P. 1611-1620.

7. Marzoog S. Synthesis of some new thiazolo[3,2-a] pyridines and related heterocyclic systems / S. Marzoog, A. Thebeiti // II Farmaco. - 2000. - Vol. 55. - P. 109-118.

8. Synthesis, anti-inflammatory and antioxidant activities of novel $3 H$-thiazolo[4,5-b]pyridines / T. I. Chaban,
V. V. Ogurtsov, V. S. Matiychuk [et al.] // Acta Chimica Slovenica. - 2019. - Vol. 66. - P. 103-111.

9. Walczyn'ski K. Non-imidazole histamine H3 ligands. Part III. New 4-n-propylpiperazines as non-imidazole histamine H3-antagonists / K. Walczyn'ski, O. P. Zuiderveld, H. Timmerman // European Journal of Medicinal Chemistry. - 2019. - Vol. 40. - P. 15-23.

10. Synthesis and structure-activity relationships of 2-(1,4'-bipiperidin-1'-yl)thiazolopyridine as H3 receptor antagonists / A. U. Rao, A. Palani, X. Chen [et al.] // Bioorganic \& Medicinal Chemitry Letters. - 2009. - Vol. 19 (21). - P. 6176-6180.

11. Kulkarni S. S. Discovery of heterobicyclic templates for novel metabotropic glutamate receptor subtype 5 antagonists / S. S. Kulkarni, A. H. Newman // Bioorganic \& Medicinal Chemisty Letters. - 2007. - Vol. 17. - P. 2987-2992.

12. Design, synthesis, and biological activity of novel factor Xa inhibitors: Improving metabolic stability by S1 and S4 ligand / S. Komoriya, S. Kobayashi, K. Osanai [et al.] // Bioorganic Medicinal Chemistry. - 2006. - Vol. 5. - P. 13091330 .

13. Synthesis of novel thiazolo[4,5-b]pyridines as potential biologically active substances / T. I. Chaban, O. V. Klenina, B. S. Zimenkovsky [et al.] // Der Pharma Chemica. - 2016. - Vol. 8 (19). - P. 534-542.

14. Kaminskyy D. Synthesis and in vitro anticancer activity of 2,4-azolidinedione-acetic acids derivatives / D. Kaminskyy, B. Zimenkovsky, R. Lesyk // European Journal of Medicinal Chemistry. - 2009. - Vol. 44 (9). - P. 3627-3636. 
Синтез біологічно активних сполук

Synthesis of biologically active compounds

\section{References}

1. Mashkovsky MD. Medicinal products. [Лекарственные средства]. Moscow: New Wave; 2010. Russian.

2. Lesyk RB, Zimenkovsky BS. 4-Thiazolidones: centenarian history, current status and perspectives for modern organic and medicinal chemistry. Current Organic Chemistry. 2004;8(16): 1547-79.

3. Chaban TI, Klenina O.V, Chaban, IG, Ogurtsov VV, Lelyukh M. Thiazolo[5,4- $d$ ]pyrimidines and thiazolo[4,5- $d]$ pyrimidines: A review on synthesis and pharmacological importance of their derivatives. Pharmacia. 2018;65(2): 54-70.

4. Smirnova NG, Zavarzin IV, Krayushkin MM. Synthesis of condensed thiazoles. Chemistry of Heterocyclic Compounds. 2006;42: 144-65.

5. Sayed HH, Morsy EMH, Kotb ER. Facile novel synthesis and reactions of thiazolidin-4-one derivatives for antimicrobial agents. Synthetic communications. 2010;40: 2712-22.

6. Chaban TI, Ogurtsov VV, Chaban IG, Klenina OV, Komarytsia JD. Synthesis and antioxidant activity evaluation of novel 5,7-dimethyl-3H-thiazolo[4,5-b]pyridines. Phosphorus, Sulfur Silicon Relat. Elem. 2013;188: 1611-20.

7. Marzoog S, Thebeiti A. Synthesis of some new thiazolo[3,2-a]pyridines and related heterocyclic systems. II Farmaco. 2000;55: 109-18.

8. Chaban TI, Ogurtsov VV, Matiychuk VS, Chaban IG, Demchuk IL, Nektegayev IA. Synthesis, anti-inflammatory and antioxidant activities of novel $3 \mathrm{H}$-thiazolo[4,5-b]pyridines. Acta Chimica Slovenica. 2019;66: 103-11.
9. Walczyn'ski K, Zuiderveld OP, Timmerman H. Nonimidazole histamine H3 ligands. Part III. New 4-n-propylpiperazines as non-imidazole histamine H3-antagonists. European Journal of Medicinal Chemistry. 2019;40: 15-23. 10. Rao $A U$, Palani $A$, Chen $X$, Huang $Y$, Aslanian RG, West RE, Williams SM, We RL, Sondey C, Lachowicz J. Synthesis and structure-activity relationships of 2-(1,4'-bipiperidin1'-yl)thiazolopyridine as $\mathrm{H} 3$ receptor antagonists. Bioorganic \& Medicinal Chemitry Letters. 2009;19(21): 6176-80.

11. Kulkarni SS, Newman AH. Discovery of heterobicyclic templates for novel metabotropic glutamate receptor subtype 5 antagonists. Bioorganic \& Medicinal Chemisty Letters. 2007;17: 2987-92.

12. Komoriya S, Kobayashi S, Osanai K, Yoshino T, Nagata T, Haginoya N, Nakamoto $Y$, Mochizuk A, Nagahara T, Suzuki M, Shimada T, Watanabe K, Isobe Y, Furugoori T. Design, synthesis, and biological activity of novel factor Xa inhibitors: Improving metabolic stability by S1 and S4 ligand. Bioorganic Medicinal Chemistry. 2006;5: 1309-30.

13. Chaban TI, Klenina OV, Zimenkovsky BS, Chaban IG, Ogurtsov VV, Shelepeten LS. Synthesis of novel thiazolo[4,5- $b]$ pyridines as potential biologically active substances. Der Pharma Chemica. 2016;8(19): 534-42.

14. Kaminskyy D, Zimenkovsky B, Lesyk R. Synthesis and in vitro anticancer activity of 2,4-azolidinedione-acetic acids derivatives. European Journal of Medicinal Chemistry. 2009;44(9): 3627-36.

Надійшла до редакції / Received: 05.02.2019 Після доопрацювання / Revised: 15.02.2019, 06.03.2019 Прийнято до друку / Accepted: 20.03.2019

\section{Відомості про авторів:}

Чабан T.І. - канд. фрармац. н., доц. каф. загальної, біонеорганічної, фрізколоїдної хімії, Львівський національний медичний університет імені Данила Галицького, Львів, Україна. E-mail: chabantaras@ukr.net, ORCID 0000-00030618-275X

Information about authors:

Chaban T.I. - PhD (Pharmaceutical Sciences), Associate Professor of the General, Bioinorganic, Physical and Colloidal Chemistry Department, Danylo Halytsky Lviv National Medical University, Lviv, Ukraine. E-mail: chabantaras@ukr.net, ORCID 0000-0003-0618-275X 